\title{
Evaluation of Dissolved Organic Matter Removal Characteristics in GAC Adsorption Process in Drinking Water Treatment Process using LC-OCD-OND
}

\author{
Heejong Son ${ }^{\dagger} \cdot$ Hoon-Sik Yoom $^{\oplus} \cdot$ Chang-Dong Seo $^{\oplus} \cdot$ Sang-Goo Kim ${ }^{\oplus} \cdot$ Yong-Soon Kim ${ }^{\odot}$ \\ Water Quality Institute, Busan Water Authority
}

(Received March 18, 2020; Revised April 9, 2020; Accepted April 27, 2020)

Objectives: In this study, we used liquid chromatograph-organic carbon detector-organic nitrogen detector (LC-OCD-OND) to evaluate adsorption and breakthrough characteristics of NOM fractions (biopolymers (BP), humic substances (HS), building blocks (BB) and low molecular weight organic substances (LMW-O)) according to the various characteristics of the different materials of granular activated carbons (GACs).

Methods: Breakthrough characteristics, adsorption capacity and partition coefficients were evaluated by NOM fractions (BP, HS, BB, and LMW-O) using a lab-scale GAC adsorption column filled with coal-, coconut- and wood-based GAC. The GAC column test was operated with 10 minutes empty bed contact time (EBCT). The pore characteristics of each GAC were evaluated using an automated gas sorption analyzer (Autosorb iQ3, Quantachrome, USA) and the concentrations of NOM fractions in the influent and effluent were analyzed using chromatography LC-OCD-OND (Model 8, DOC-Labor, Germany).

Results and Discussion: NOM adsorption capacity was evaluated for different materials of laboratory scale GAC adsorption column test. To study the adsorption behavior of individual NOM fractions according to the operation time, NOM was fractionated into BP, HS, BB and LMW-O by LC-OCD-OND, and the individual NOM fractions were quantified. Higher MW like BP was not adsorbed to GAC, in contrast, HS, BB, and LMW-O were well removed during the initial operation period, the concentrations in the effluent gradually increased as increase the operation period until reaching to the pseudo steady-state. Poor removal of BP in GAC adsorption may be a result of blocking the pores with large MW BP and hinder the access to the pores. However, in the case of HS, BB, and LMW-O, as the molecular size decreased, these organic matters easily access to the pores inside of GAC. It was confirmed through the partition coefficient that the adsorption capacity of these NOM fractions increased in proportion to the MW. In addition, in order to achieve a high NOM removal efficiency in the GAC adsorption process, not only the specific surface area, pore volume, and pore width of the GAC must be large, but also the $\mathrm{pH}_{\mathrm{zpc}}$ must be higher than the neutral $\mathrm{pH}$ level.

Conclusions: In order to achieve a high NOM removal efficiency in the GAC adsorption process, not only the specific surface area, pore volume, and pore width of the GAC must be large, but also the $\mathrm{pH}_{\mathrm{zpc}}$ must be higher than the neutral $\mathrm{pH}$ level. In addition, in the NOM fractions, BP were not adsorbed to GAC, while the adsorption capacity of the remaining NOM fractions increased as the MW of the NOM fractions decreased. LMW-O was the most adsorbed, followed by BB, HS and BP. BP and HS play an important role in the membrane fouling that are introduced a lot into domestic and foreign water treatment plants. This study showed that the BP was not removed by the adsorption mechanism of the GAC process. In addition, HS was adsorbed and removed at the beginning of the operation, but the adsorption capacity of HS decreased rapidly as the operation period increased compared to other NOM fractions. Therefore, the GAC adsorption process is not expected to be an effective pre-treatment technology for reducing membrane foulants. Previous studies showed that the yields of DBPs $(\mu \mathrm{mol} \cdot \mathrm{DBP} / \mu \mathrm{mol} \cdot \mathrm{C})$ in the high $\mathrm{MW}$ humic and low MW non-humic fractions are similar. Therefore, it is suggested that the GAC adsorption process is more effective for DBP precursor control in water containing a larger percentage of LMW NOM.

Key Words: Natural Organic Matter (NOM), Adsorption, Granular Activated Carbon (GAC), NOM Fraction, LC-OCD-OND 


\title{
LC-OCD-OND를 이용한 정수처리용 GAC 흡착공정에서 용존유기물질 제거특성 평가
}

\author{
손희종 ${ }^{\dagger} \cdot$ 염훈식 $^{\odot} \cdot$ 서창동 $^{\circledR} \cdot$ 김상구 $^{\circledR} \cdot$ 김용순 $^{\circledR}$ \\ 부산광역시 상수도사업본부 수질연구소
}

목적 : 본 연구에서는 입상활성탄(granular activated carbon, GAC) 흡착공정에서 활성탄의 다양한 특성에 따른 NOM 분획별 흡착 및 파과 특성을 평가하기 위하여 liquid chromatograph-organic carbon detector-organic nitrogen detector (LC-OCD-OND)를 이용하였으며, NOM 분획별(biopolymers (BP), humic substances (HS), building blocks (BB), low molecular weight (LMW) 유기물질) 파과 특성을 평가하여 활성탄의 특성이 NOM 흡착에 미치는 영향을 파악하고자 하였다.

방법 : 본 연구에서는 석탄계, 야자계 및 목탄계 재질 활성탄들을 충진한 실험실 규모의 GAC 흡착컬럼을 이용하 여 $\mathrm{NOM}$ 분획별(BP, HS, BB 및 LMW-O)로 파과 특성, 흡착용량 및 분배계수를 평가하였다. 실험실 규모의 GAC 흡착컬럼은 공탑체류시간 10 분으로 고정하여 운전하였다. 활성탄 재질별 공극 특성은 automated gas sorption analyzer (Autosorb $\mathrm{iQ}_{3}$, Quantachrome, USA)를 이용 평가하였으며, 유입수와 유출수 중의 $\mathrm{NOM}$ 분획들의 농도 는 크기 배제 크로마토그래피인 LC-OCD-OND (Model 8, DOC-Labor, Germany)를 이용하여 분석하였다.

결과 및 토의: 실험실 규모의 GAC 흡착컬럼에서 다양한 재질의 $\mathrm{GAC}$ 에 대해 $\mathrm{NOM}$ 흡착능을 평가하였다. 운전 기간에 따른 개별 $\mathrm{NOM}$ 분획의 흡착 거동을 연구하기 위해, LC-OCD-OND을 이용하여 $\mathrm{BP}, \mathrm{HS}, \mathrm{BB}$ 및 LMW-O 로 분별하고, $\mathrm{NOM}$ 분획들을 정량화하였다. 고분자인 $\mathrm{BP}$ 는 $\mathrm{GAC}$ 에는 흡착되지 않았으며, 대조적으로, $\mathrm{HS}, \mathrm{BB}$ 및 $\mathrm{LMW}-\mathrm{O}$ 는 초기에 양호하게 제거되었으나 운전기간 증가에 따라 유출수 중의 농도는 pseudo steady-state에 도달할 때까지 점진적으로 증가하였다. $\mathrm{GAC}$ 흡착에서 $\mathrm{BP}$ 의 불량한 제거는 큰 분자량인 $\mathrm{BP}$ 가 $\mathrm{GAC}$ pore를 blocking하여 세공으로 접근이 차단된 결과일 수 있다. 그러나 $\mathrm{HS}, \mathrm{BB}$ 및 LMW-O의 경우, 분자 크기가 감소함 에 따라 $\mathrm{GAC}$ 내부 세공으로의 접근이 용이해져 이들 $\mathrm{NOM}$ 분획의 흡착능이 분자량에 비례하여 증가한 것을 분배계수를 통하여 확인할 수 있었다. 또한, $\mathrm{GAC}$ 흡착공정에서 높은 $\mathrm{NOM}$ 제거 효율을 달성하려면 활성탄이 가지는 세공의 비표면적, 세공용적 및 세공의 폭이 커야 할 뿐만 아니라 $\mathrm{pH}_{\mathrm{zpc}}$ 도 중성 $\mathrm{pH}$ 부근 이상으로 높아야 NOM 흡착능이 높게 나타났다.

결론: $\mathrm{GAC}$ 흡착공정에서 높은 $\mathrm{NOM}$ 제거 효율을 달성하려면 활성탄이 가지는 세공의 비표면적, 세공용적 및 세공의 폭이 커야 할 뿐만 아니라 $\mathrm{pH}_{\mathrm{zpc}}$ 도 중성 $\mathrm{pH}$ 부근 이상으로 높아야 했다. 또한, $\mathrm{NOM}$ 분획들에서는 $\mathrm{BP}$ 가 $\mathrm{GAC}$ 에 흡착되지 않은 반면, 나머지 $\mathrm{NOM}$ 분획의 흡착능은 $\mathrm{NOM}$ 분획들의 분자량이 감소함에 따라 증가하였 다. $\mathrm{LMW}-\mathrm{O}$ 가 가장 많이 흡착되었고, 다음으로 $\mathrm{BB}, \mathrm{HS}, \mathrm{BP}$ 순으로 나타났다. $\mathrm{BP}$ 와 $\mathrm{HS}$ 는 국내·외 정수장에 많 이 도입되어 있는 membrane의 오염에 있어서 중요한 역할을 한다. 본 연구에서는 $\mathrm{GAC}$ 공정의 흡착 메카니즘으 로는 $\mathrm{BP}$ 가 제거되지 않았음을 보여주었다. 또한, $\mathrm{HS}$ 는 운전 초기에는 흡착 제거되었으나 운전 기간이 증가할수 록 다른 $\mathrm{NOM}$ 분획들에 비해 급격히 흡착 용량이 감소하였다. 따라서 $\mathrm{GAC}$ 흡착공정은 membrane의 오염물질 제거를 위한 효과적인 전처리 기술이 될 것으로 기대되지는 않는다. DBPs 전구물질의 관점에서 보면 이전 연구 결과에서 고분자 휴믹물질과 저분자 비휴믹 분획들에서의 $\mathrm{DBPs}$ 생성수율 $(\mu \mathrm{mol} \mathrm{DBP} / \mu \mathrm{mol} \mathrm{C})$ 이 유사하다는 것 을 보여주었다. 따라서 $\mathrm{GAC}$ 흡착공정은 더 높은 비율의 저분자 $\mathrm{NOM}$ 을 함유하는 물에서 $\mathrm{DBP}$ 전구물질 제어 에 더 효과적임을 시사한다.

주제어 : 천연유기물질, 흡착, 입상활성탄, 천연유기물질 분획, LC-OCD-OND 


\section{1. 서론}

원수 중에 잔존하는 천연유기물질(natural organic matter, $\mathrm{NOM}$ )은 정수처리 공정의 선택, 설계, 운영 및 처리수의 수질 에 많은 영향을 미친다. 예를 들면, 응집제와 산화제 요구량의 증가, 막 오염 유발, 소독부산물(disinfection by-products, $\mathrm{DBPs}$ ) 전구물질의 제공 등이다.

일반적으로 수중의 NOM 농도는 유기탄소(organic carbon) 농도와 UV 흡광도 $(254 \mathrm{~nm})$ 를 측정하여 총량적인 농도로 평가 하고 있다. 그러나 수중의 NOM은 저분자에서 고분자까지 다 양한 분자량대 및 친수성 물질에서 소수성 물질까지 다양한 특성을 가진 유기물질들의 혼합체로 잔존하하기 때문에 유기 탄소 및 UV 흡광도 농도가 유사한 수준이라도 염소와 같은 소독제와의 반응성, 막 오염 유발 특성 및 배·급수관망에서의 생물학적 안전성 등에는 많은 차이를 유발한다. ${ }^{2-4)}$ 이러한 총 량적인 지표들은 $\mathrm{NOM}$ 의 농도에 관한 정보만 제공할 뿐 특성 에 관한 정보의 제공에는 한계가 있다. ${ }^{5}$

최근에는 수중에 함유된 복잡한 $\mathrm{NOM}$ 의 구조적 특성 분석을 위해 크로마토그래피 및 분광학적 원리를 이용한 다양한 방 법들이 이용되고 있다. ${ }^{6,7)}$ 특히, size exclusion chromatography 원리를 이용한 LC-OCD (liquid chromatography-organic carbon detector)는 수중의 NOM 농도 및 특성 평가에 매우 적합한 방법들로 알려져 있다. ${ }^{8-10)}$

강물이나 호소수를 이용하여 수돗물을 생산하는 국내의 대 규모 정수장들은 미량유해물질, 소독부산물 전구물질 및 배. 급수관망에서 미생물 재성장 유발물질 등을 제거할 목적으로 기존 정수처리공정(응집/침전/모래여과)의 후단에 입상활성 탄(granular activated carbon, GAC) 흡착공정 및 오존과 생물 활성탄(biological activated carbon, BAC) 공정을 도입하여 운전하고 있다. ${ }^{11)}$ 특히, 상수원수 중에 함유된 다양한 미량오 염물질들에 대한 경각심 ${ }^{12-14}$ 과 $\mathrm{NOM}$ 제거에 대한 필요성의 강화 ${ }^{15,16}$ 로 인해 $\mathrm{GAC}$ 공정의 도입은 점진적으로 증가하는 실정이다.

수중에 잔존하는 NOM은 상수원이 위치한 공간적인 특성에 따라 그리고 동일한 상수원 내에서도 시간적 변화에 따라 특성 이 달라진다. ${ }^{17)}$ 따라서 $\mathrm{GAC}$ 공정에서 $\mathrm{NOM}$ 흡착 속도와 범위 는 예측하기 어렵다. ${ }^{18)}$ 분자량 분포, 소수도(hydrophobicity), 전하 분포 및 $\mathrm{GAC}$ 표면과 수소 결합을 형성하는 능력과 같은 $\mathrm{NOM}$ 특성의 다양한 측면은 $\mathrm{GAC}$ 공정에서 $\mathrm{NOM}$ 흡착능에 많은 영향을 미친다. 또한 활성탄의 물리적(표면적, 크기, 기공 의 모양과 부피) 및 화학적(표면 전하, 표면의 관능기 수) 특성 뿐만 아니라 용액의 $\mathrm{pH}$, 이온 강도 및 경도 등도 $\mathrm{NOM}$ 의 흡착 에 영향을 미친다. ${ }^{19,20)}$

물리적 영향은 $\mathrm{GAC}$ 의 세공 크기 분포에 대한 $\mathrm{NOM}$ 의 분 자량 분포에 의해 크게 좌우된다. ${ }^{21,22)}$ 수중의 $\mathrm{NOM}$ 은 중간 세공(세공 폭: 2 $50 \mathrm{~nm}$ )과 비교적 큰 미세 세공(세공 폭:
$1 \sim 2 \mathrm{~nm}$ )에 대부분 흡착된다. ${ }^{19,21,23-27)}$ 분자량 $10,000 \mathrm{Da}$ 이 상의 고분자 $\mathrm{NOM}$ 분획들은 $\mathrm{GAC}$ 에서 크기 배제 효과로 인 해 쉽게 흡착되지 않는 반면, 응집/침전공정에 의해 쉽게 제 거되기 때문에 $\mathrm{GAC}$ 공정의 유입수에는 저농도로 존재한 다. ${ }^{28,29)}$ 대조적으로 $500 \sim 4,000 \mathrm{Da}$ 정도의 중분자 NOM 분 획들은 $\mathrm{GAC}$ 공정에서 흡착에 의해 용이하게 제거된다. 500 $\mathrm{Da}$ 이하의 저분자 NOM 분획들은 물질들의 크기만 고려할 경우, $\mathrm{GAC}$ 에 형성되어 있는 대부분의 세공들에 접근이 가 능하지만 이들 저분자 NOM 분획들이 가지는 친수성 특성 으로 인하여 $\mathrm{GAC}$ 세공에서의 흡착 제거능이 낮다. 또한, $\mathrm{GAC}$ 표면에 서식하는 박테리아 군집들의 생물분해 대사산 물이 대부분 저분자 화합물들로 구성되기 때문에 $\mathrm{GAC}$ 공 정에서 이들 저분자 $\mathrm{NOM}$ 분획들의 제거율이 더욱 낮게 평 가되는 경향이 있다. ${ }^{4,29)}$

$\mathrm{GAC}$ 흡착에 영향을 미치는 화학적 상호 작용의 경우는 흡 착물, 흡착제 표면 및 시료수의 매트릭스 특성에 의해 영향을 받는다. 카르복실산과 페놀기가 NOM 구조에 존재하기 때문 에 $\mathrm{NOM}$ 은 상수원수 또는 정수처리 공정수 중의 $\mathrm{pH}$ 범위에서 음전하를 가진다. ${ }^{30)}$ 시료수의 $\mathrm{pH}, \mathrm{GAC}$ 의 재질 및 세공 활성화 공정에 의해 $\mathrm{GAC}$ 세공의 표면 전하는 양성, 음성 또는 중성이 될 수 있다. ${ }^{22)}$

결과적으로, 정전기적 상호 작용은 $\mathrm{GAC}$ 흡착공정에서 $\mathrm{NOM}$ 의 흡착에 영향을 미치지만 전반적으로 $\mathrm{GAC}$ 의 세공 크 기 분포는 정전기 효과가 보조 역할을 하는 동안 $\mathrm{GAC}$ 공정에 서 NOM 흡착 제거를 위한 주요 요인으로 작용한다. ${ }^{21,31)}$

현재까지 $\mathrm{GAC}$ 공정에서의 $\mathrm{NOM}$ 흡착에 관한 연구는 $\mathrm{DOC}$ 농도에 의존하는 총량적 개념의 연구결과들이 대부분이며 ${ }^{32,33)}$, 다만 몇몇 연구들에서는 크기배제(size exclusion) 크로마토그 래피-UV 검출기를 이용하여 $\mathrm{NOM}$ 의 분자량 크기에 따른 제거 율을 평가 ${ }^{28,29}$ 하였으나 개별 NOM 분획들에 대한 파과 곡선 (breakthrough curve)과 파과 특성에 대한 연구결과는 도출되 지 못하였다. 최근에는 $\mathrm{LC}-\mathrm{OCD}$ 를 이용하여 $\mathrm{GAC}$ 흡착컬럼에 서 biopolymers (BP), humic substances (HS), building blocks (BB), low molecular weight (LMW) 유기물질과 같은 개별 $\mathrm{NOM}$ 구성 요소들의 파과특성을 평가한 일부 연구결과들이 보고 ${ }^{34,35)}$ 되고 있으나 다양한 재질의 활성탄들의 흡착특성 비 교평가 및 파과에 도달한 이후의 거동에 대한 평가는 매우 부족한 실정이다.

따라서 본 연구에서는 LC-OCD-OND를 이용하여 (1) GAC 흡착컬럼에서 biopolymers (BP), humic substances (HS), building blocks (BB), low molecular weight (LMW) 유기물 질과 같은 개별 NOM 분획들의 파과특성을 평가하고, (2) 석탄계, 야자계 및 목탄계 재질의 활성탄들을 이용하여 다양 한 활성탄 특성에 따른 $\mathrm{NOM}$ 의 흡착 특성을 평가하고자 하였다. 
Table 1. Characteristics of dissolved organic matter concentration in influent.

\begin{tabular}{|c|c|c|c|c|c|c|c|}
\hline \multirow[t]{2}{*}{ Parameters } & \multicolumn{5}{|c|}{$\begin{array}{c}\text { DOC fractions } \\
(\mathrm{mg} / \mathrm{L})\end{array}$} & \multicolumn{2}{|c|}{$\begin{array}{c}\text { DON fractions } \\
(\mathrm{mg} / \mathrm{L})\end{array}$} \\
\hline & DOC & BP & HS & BB & LMW-O & BP & HS \\
\hline Value & $1.89 \pm 0.43$ & $0.13 \pm 0.07$ & $0.89 \pm 0.14$ & $0.37 \pm 0.05$ & $0.39 \pm 0.20$ & $0.01 \pm 0.01$ & $0.04 \pm 0.01$ \\
\hline
\end{tabular}

Table 2. Physicochemical properties of coal-, coconut- and wood-based GACs.

\begin{tabular}{ccccc} 
GAC materials & & Coal & Coconut & Wood \\
Specific surface area & $\left(\mathrm{m}^{2} / \mathrm{g}\right)$ & 1,122 & 1,152 & 1,602 \\
Total pore volume & $\left(\mathrm{cm}^{3} / \mathrm{g}\right)$ & 0.641 & 0.599 & 1.125 \\
Mean pore radius & $(\AA)$ & 23 & 18 & 28 \\
$\mathrm{pH}_{\mathrm{zpc}}^{*}$ & $(-)$ & 7.0 & 6.5 & 4.1 \\
\hline
\end{tabular}

${ }^{*} \mathrm{pH} \mathrm{zpc}_{\mathrm{pc}}$ is $\mathrm{pH}$ of the isoelectric point.

\section{2. 실험재료 및 방법}

\section{1. 실험 재료}

\subsubsection{GAC 흡착컬럼 유입수 성상}

$\mathrm{GAC}$ 흡착컬럼의 유입수로는 300 톤/일 처리용량의 파일롯 트 플랜트의 후오존 처리수를 실험에 사용하였으며, 파일롯트 플랜트는 낙동강 원수를 취수하여 전오존, 응집/침전, 급속모 래여과, 후오존, $\mathrm{BAC}$ 공정으로 구성되어져 있다. 실험기간 동안의 $\mathrm{GAC}$ 흡착컬럼 유입수 성상을 Table1에 나타내었다. $\mathrm{DOC}$ 농도는 평균 $1.89 \mathrm{mg} / \mathrm{L}$ 정도였으며, $\mathrm{NOM}$ 분획들 중에 서 $\mathrm{HS}$ 의 평균 농도가 $0.89 \mathrm{mg} / \mathrm{L}$ 로 유입수 전체 $\mathrm{NOM}$ 의 $50 \%$ 정도를 차지하였다. 또한, $\mathrm{BP}$ 와 $\mathrm{HS}$ 에 함유되어 있는 용존 유 기질소(DON) 평균농도는 각각 $0.01 \mathrm{mg} / \mathrm{L}$ 및 $0.04 \mathrm{mg} / \mathrm{L}$ 로 $\mathrm{DOC}$ 농도에 비해 매우 낮은 것으로 나타났다. Table 1에는 나타내지 않았으나 $\mathrm{pH}$ 와 수온은 각각 6.8 7.4 및 $15 \sim 24^{\circ} \mathrm{C}$ 범위였다.

\subsubsection{GAC 성상}

실험에 사용된 GAC들은 석탄계 재질(F400, Calgon, USA), 야자계 재질(Samchully, Korea) 및 목탄계 재질(Pica, Picabiol, France)를 이용하였다. 활성탄들은 실험에 사용하기 전에 18 32 mesh $(0.5 \sim 1.0 \mathrm{~mm})$ 로 체거름한 후 초순수에 세척·건조 하여 사용하였다. 실험에 사용된 활성탄들에 대한 물리·화학 적 특성을 Table2에 나타내었으며, 세공용적 분포를 Fig.1에 나타내었다.

활성탄 재질별 비표면적과 세공용적을 비교해보면 목탄계 활성탄의 비표면적과 세공용적이 각각 $1,602 \mathrm{~m}^{2} / \mathrm{g}$ 과 1.125 $\mathrm{cm}^{3} / \mathrm{g}$ 으로 가장 높게 나타났으며, 석탄계와 야자계 활성탄의 경우는 세공용적과 비표면적 값에 큰 차이는 없었다. 평균 세공의 반경은 목탄계 활성탄이 $28 \AA$ 으로 가장 컸으며, 다음 으로 석탄계가 $23 \AA$, 야자계가 $18 \AA$ 으로 나타났다. 또한, $\mathrm{pH}_{\mathrm{zpc}}$ 의 경우는 석탄계와 야자계의 7.0과 6.5에 비해 목탄계

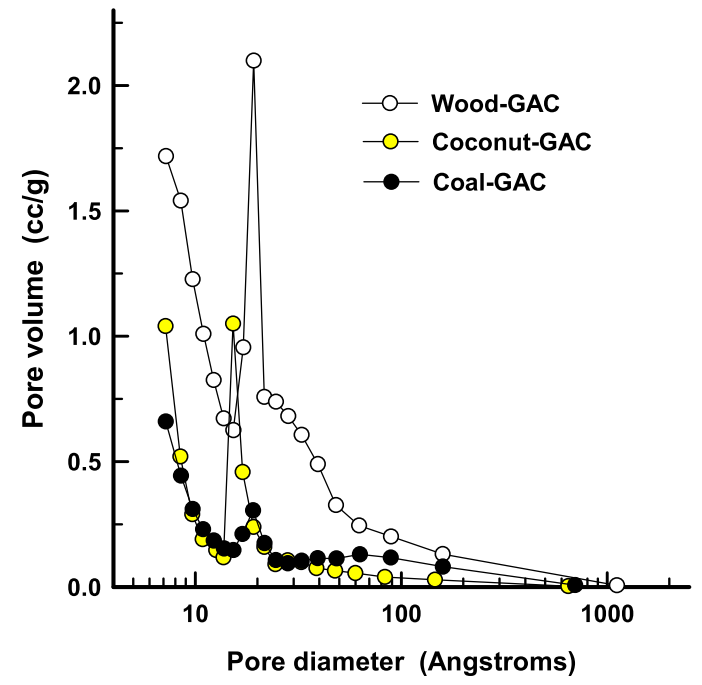

Fig. 1. Distributions of pore volume with pore size.

재질의 활성탄이 4.1로 나타나 많은 차이를 보였다.

\section{2. 실험 방법}

\subsubsection{GAC 흡착실험}

본 실험에는 실험실 규모의 $\mathrm{GAC}$ 흡착컬럼을 사용하였다. 컬럼은 아크릴 재질로 내경 $2.3 \mathrm{~cm}$, 높이 $50 \mathrm{~cm}$ 이며, 총 4 개의 컬럼에 석탄계, 야자계 및 목탄계 활성탄을 각각 $60 \mathrm{~mL}$ 씩 충진하였다. Fig. 2에서 볼 수 있듯이 정량펌프를 이용하여 각각의 컬럼 상부로 $6 \mathrm{~mL} / \mathrm{min}$ 의 유량으로 유입수를 주입하여 하향류 방식으로 운전하였고, 각 GAC 컬럼의 공탑체류시간 (empty bed contact time, $\mathrm{EBCT}$ )은 10 분으로 고정하여 운전하 였다. 역세척은 주 1 회 실시하였다.

\subsubsection{NOM 분석}

$\mathrm{DOC}$ 와 $\mathrm{NOM}$ 분획별 농도는 LC-OCD-OND (Model 8, DOC-Labor, Germany) 시스템을 이용하였다. LC-OCD-OND 

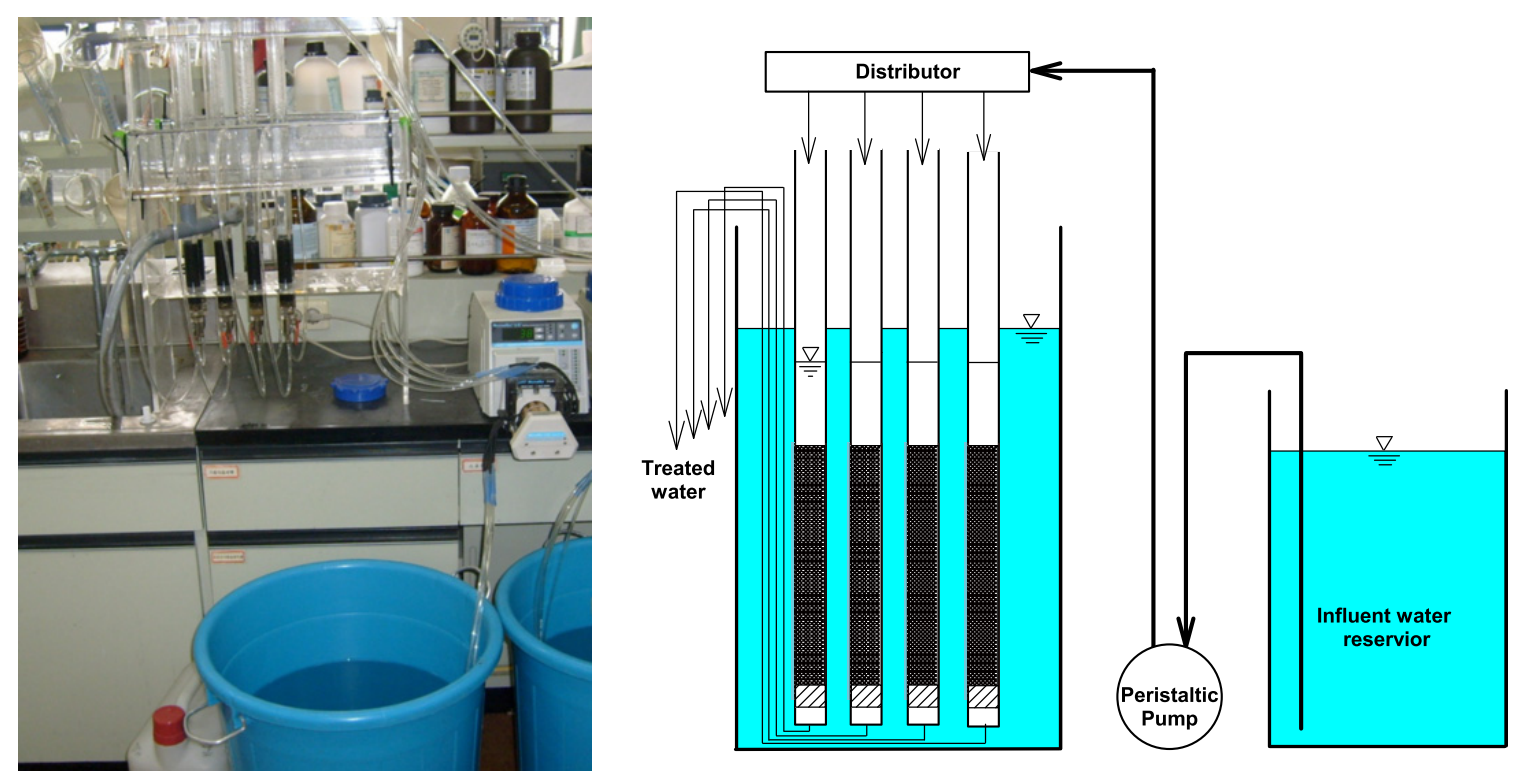

Fig. 2. Photograph (left) and schematic diagram (right) of lab-scale GAC adsorption column system.

Table 3. The fractions and characteristics from LC-OCD-OND.

\begin{tabular}{|c|c|c|c|c|c|}
\hline \multirow{2}{*}{$\begin{array}{c}\text { Name } \\
\text { (Abbreviation) }\end{array}$} & \multirow{2}{*}{$\begin{array}{l}\text { Biopolymers } \\
\text { (BP) }\end{array}$} & \multirow{2}{*}{$\begin{array}{l}\text { Humic substances } \\
\text { (HS) }\end{array}$} & \multirow{2}{*}{$\begin{array}{l}\text { Building blocks } \\
\text { (BB) }\end{array}$} & \multicolumn{2}{|c|}{$\begin{array}{l}\text { LMW organics } \\
(\mathrm{LMW}-\mathrm{O})\end{array}$} \\
\hline & & & & $\begin{array}{l}\text { LMW acids } \\
\text { (LMW-A) }\end{array}$ & $\begin{array}{l}\text { LMW neutrals } \\
\text { (LMW-N) }\end{array}$ \\
\hline $\mathrm{MW}(\mathrm{g} / \mathrm{mol})$ & $>20,000$ & $\sim 1,000$ & $300 \sim 500$ & $<350$ & $<350$ \\
\hline Description & $\begin{array}{l}\text { High molecular } \\
\text { polysaccharides, proteins } \\
\text { and amino sugars }\end{array}$ & $\begin{array}{l}\text { Humic acids and fulvic } \\
\text { acids }\end{array}$ & $\begin{array}{l}\text { Degradation products } \\
\text { from HS }\end{array}$ & $\begin{array}{l}\text { Final degradation } \\
\text { products of organic but } \\
\text { also released by bacteria }\end{array}$ & $\begin{array}{c}\text { Alcohols, aldehydes } \\
\text { ketones, sugars and } \\
\text { amino acids }\end{array}$ \\
\hline
\end{tabular}

시스템은 size exclusion chromatography (SEC) 컬럼 (Toyopearl TSK HW-50S, 250×20 mm, Japan) 및 ultraviolet detector (UVD), organic carbon detector (OCD) 및 organic nitrogen detector (OND)가 장착되어 있으며, 분석 전에 모든 시료는 $0.45 \mu \mathrm{m}$ 멤브레인 여지(Millipore, USA)로 여과하여 분석하였다. 분석 결과는 NOM을 5 개의 그룹(biopolymers, humic substances, building blocks, low molecular weight (LMW) acids 및 LMW neutrals)으로 분류하여 정성·정량이 가능하다. 이동상으로는 phosphate buffer를 사용하였고, 산 화제를 주입하여 gräntzel thin film reactor에서 유기물질을 완전 산화시키며, 정량한계는 $0.01 \mathrm{mg} \cdot \mathrm{C} / \mathrm{L}$ 이다. Table 3에는 LC-OCD-OND 시스템에서 분석하는 5 개의 NOM 그룹에 대 한 특성을 나타내었다.

\subsection{3. 입상활성탄 성상 분석}

본 연구에 사용된 석탄계, 야자계 및 목탄계 재질의 입상활 성탄(GAC)의 세공용적(total pore volume), 비표면적(specific surface area) 및 평균 세공크기(mean pore radius)는 automated gas sorption analyzer (Autosorb $\mathrm{iQ}_{3}$, Quantachrome, USA)로 측정하였다.

\subsection{4. 유기물질 흡착능 평가}

$\mathrm{DOC}$ 와 $\mathrm{NOM}$ 분획별 흡착용량 $(q)$ 계산에는 석탄계, 야자계 및 목탄계 입상활성탄을 충진한 흡착컬럼에서의 물질별 파과 시점까지의 유입농도와 유출농도를 이용하여 식 (1)에 나타낸 Freundlich 등온흡착식으로 도출하였다. 그리고 DOC와 NOM 분획별 분배계수 $\left(K_{p}\right)$ 는 Velten 등 ${ }^{34)}$ 이 사용한 식 (2)를 이용하 여 도출하였다. 흡착용량 $(q)$ 는 입상활성탄에 흡착된 $\mathrm{DOC}$ 와 $\mathrm{NOM}$ 분획들의 농도 $(\mathrm{mg} \cdot \mathrm{C} / \mathrm{g} \cdot \mathrm{GAC})$ 이며, 분배계수 $\left(K_{p}\right)$ 는 정 상상태 조건에서 고체상 $(q)$ 및 수용액상 $(C)$ 에서의 $\mathrm{DOC}$ 와 $\mathrm{NOM}$ 분획의 농도인 $q_{e}$ 및 $C_{e}$ 의 비로부터 계산되었다.

$$
q_{e}=k \cdot C_{e}^{l / n}
$$

$q_{e}=$ the solid phase equilibrium concentration $(\mathrm{mg} / \mathrm{g})$

$C_{e}=$ the aqueous phase equilibrium concentration $(\mathrm{mg} / \mathrm{L})$

$k, 1 / n=$ constants characteristic of the system

$$
K_{p}=q_{e} / C_{e}
$$

$K_{p}=$ partition coefficient, the ratio of solid and aqueous-phase concentrations $(\mathrm{L} / \mathrm{g})$ 


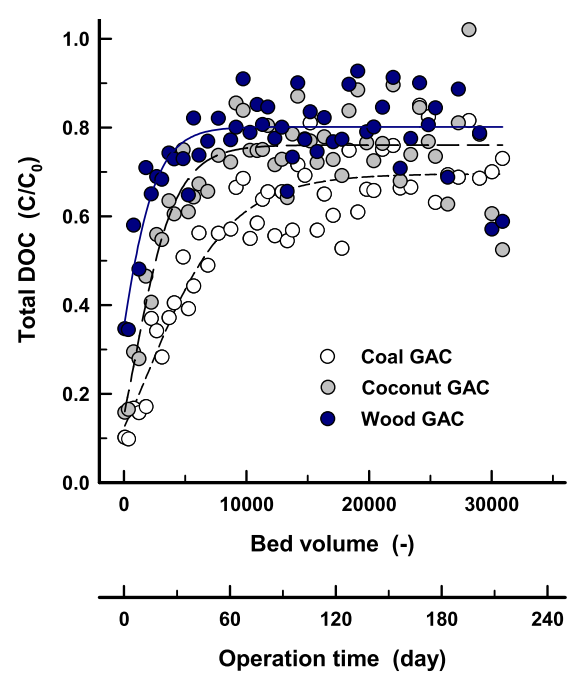

Fig. 3. DOC breakthrough curves by activated carbon material.

\section{3. 결과 및 고찰}

\section{1. 활성탄 재질별 NOM 파과특성}

활성탄 재질별 DOC에 대한 파과 곡선을 Fig. 3에 나타내었
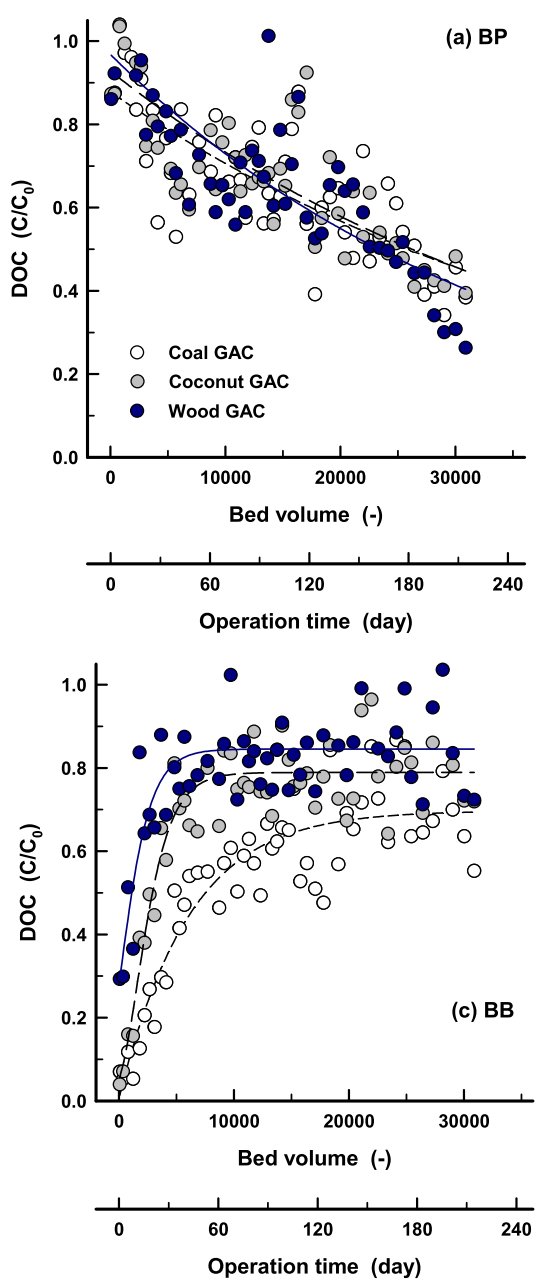

다. 목탄계 재질의 활성탄은 BV 7,600 부근(운전일수 53 일)에 서 정상상태에 도달하였으며, 파과 도달 이후의 $\mathrm{DOC}$ 제거율 은 20\% (잔존비 0.8) 정도를 유지하였다. 야자계 활성탄의 경 우는 BV 9,500 부근(운전일수 66일)에서 파과에 도달하였으 며, 파과 이후에는 $\mathrm{DOC}$ 제거율이 $24 \%$ (잔존비 0.76 ) 정도로 나타났다. 또한, 가장 늦게 파과에 도달한 석탄계 활성탄의 경우는 BV 16,200 이후(운전일수 113 일)에 파과에 도달하여 파과 이후 $31 \%$ 정도의 $\mathrm{DOC}$ 제거율을 나타내었다. 따라서 활 성탄 재질별로 각각 파과에 도달하는 기간과 파과 이후의 $\mathrm{DOC}$ 제거율이 모두 상이하게 나타나고 있으며, $\mathrm{DOC}$ 흡착능은 석 탄계 재질의 활성탄이 가장 우수한 것으로 나타났고, 다음으 로 야자계 및 목탄계 재질의 활성탄 순으로 조사되었다.

다양한 재질의 활성탄들에서의 NOM 흡착 특성을 세부적으 로 평가하기 위해 LC-OCD를 이용하여 NOM 분획별로 운전 기간 증가에 따른 잔존비 변화 평가결과를 Fig.4에 나타내었 다. Fig. 4(a)에 나타낸 biopolymers (BP)의 경우, 3 가지 재질의 활성탄 모두 운전 초기에는 $\mathrm{BP}$ 가 흡착·제거되지 않았으나 운전기간이 경과할수록 제거율이 점진적으로 증가하였다. $\mathrm{BV}$ 20,000 부근에서는 유입되는 BP 농도의 $50 \%$ 정도가 제거되었
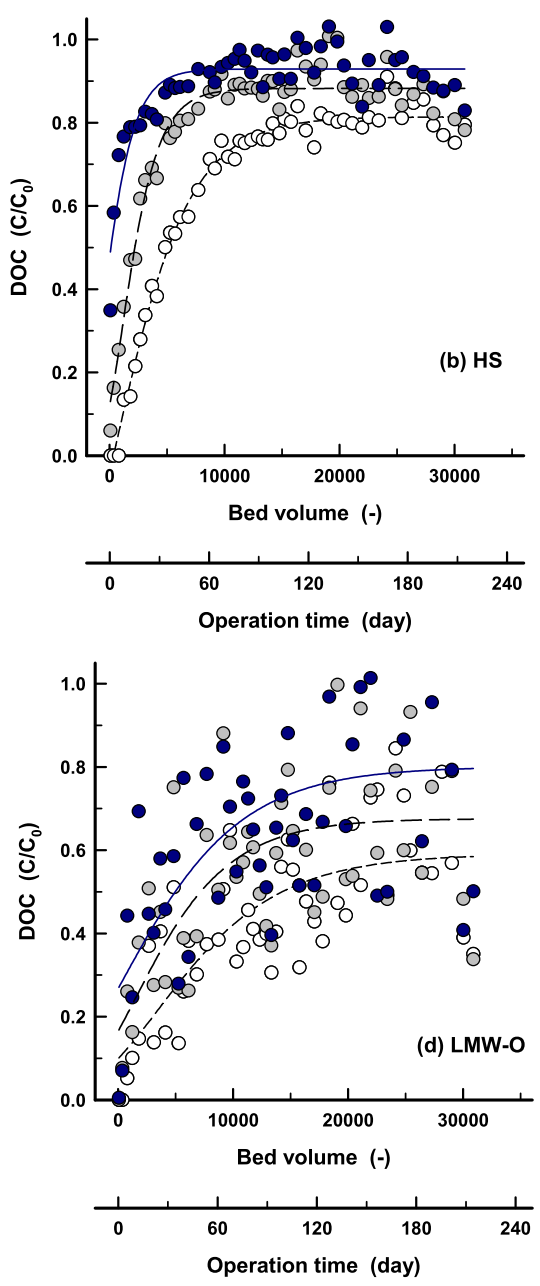

Fig. 4. Breakthrough curves of individual NOM fractions by coal-, coconut- and wood-based GACs. 
다. $\mathrm{BP}$ 는 다당류, 단백질류 및 아미노당류 등으로 구성된 분자 량 $20,000 \mathrm{~g} / \mathrm{mol}$ 이상의 고분자 유기물질로 pore blocking에 의해 활성탄 세공으로의 흡착은 차단된다. ${ }^{34)}$ 따라서 $\mathrm{GAC}$ 흡 착컬럼에서 운전 초기에는 다른 용존 유기물질 분획에 비해 $\mathrm{BP}$ 의 경우 흡착에 의해 용이하게 제거되지 않았다. $\mathrm{LC}-\mathrm{OCD}$ 를 이용하여 수중의 용존 유기물질들에 대한 생물분해 특성을 평가한 Son 등의 연구결과 ${ }^{4}$ 에서는 $\mathrm{BP}$ 는 다른 분획들에 비하 여 가장 용이하고 빠르게 생물분해되는 것으로 보고하고 있 다. 따라서 Fig. 4(a)의 경우와 같이 GAC 흡착컬럼의 운전기간 의 증가에 비례하여 $\mathrm{BP}$ 의 제거율이 점진적으로 증가하는 것 은 입상활성탄 표면에 종속영양성 박테리아들이 부착되어 생 물활성탄으로 전환되면서 나타난 결과이다.

Fig. 4(b) (d)에는 humic substances (HS), building blocks (BB) 및 $\mathrm{LMW}$ organics (LMW-O)에 대한 운전기간 증가에 따른 잔존비 변화 평가결과를 나타내었다. 이들은 $\mathrm{BP}$ 와는 달 리 활성탄 흡착컬럼 운전초기에는 흡착·제거되어 유출수에서 의 잔존비가 낮게 나타났으나 운전기간이 증가할수록 잔존비 가 증가하는 경향을 나타내었다. 이들의 평균 분자량은 $\mathrm{BP}$ 와 는 달리 $\mathrm{HS}, \mathrm{BB}$ 및 $\mathrm{LMW}-\mathrm{O}$ 가 각각 $1,000 \mathrm{Da}, 300 \sim 500 \mathrm{Da}$ 및 <350 Da이어서 물질의 크기와 활성탄 세공의 크기만으로 비교해 볼 때 중간세공(mesopore)이나 비교적 큰 미세세공 (micropore)에 흡착이 가능한다. ${ }^{36,37)}$

Fig. 4(b) (d)에서 볼 수 있듯이 $\mathrm{HS}, \mathrm{BB}$ 및 $\mathrm{LMW}-\mathrm{O}$ 의 경우 운전기간 증가에 따른 잔존비는 점진적으로 증가하다가 정상 상태(pseudo steady-state)에 도달한 이후 더 이상의 증가는 나 타나지 않았다. 이는 $\mathrm{HS}, \mathrm{BB}$ 및 $\mathrm{LMW}-\mathrm{O}$ 가 활성탄에 흡착되어 파과가 진행되면서 세공 내에서 생물분해가 동시에 유발되어 일정한 흡착능이 유지되는 것을 의미하며 이를 생물학적 재생 으로 평가한다. ${ }^{38)}$ 일반적으로 humic substances (HS)의 경우는 매우 난분해성으로 알려져 있어 생물분해에 내성이 강한 것으 로 알려져 있으나 $\mathrm{BDOC}$ 배양법을 이용하여 수중의 $\mathrm{HS}$ 성분 에 대한 생물분해능을 조사한 Son 등의 연구결과 ${ }^{4}$ 에서 초기 $\mathrm{HS}$ 농도의 $10 \sim 20 \%$ 정도가 생물분해되어 제거된 것으로 보고
하고 있다. $\mathrm{HS}$ 의 경우, 유입농도와 유출농도가 동일해지는 $\left(\mathrm{C} / \mathrm{C}_{0}=1\right)$ 파과(breakthrough)에 도달하지는 않았으며, 정상상 태 도달 이후 각각의 활성탄 재질별로 거의 일정한 HS 제거율 을 나타내는 것을 볼 수 있다. 활성탄 재질별 정상상태에 도달 한 $\mathrm{BV}$ 와 정상상태 도달 이후의 제거율을 살펴보면 목탄계는 $\mathrm{BV} 6,800$ 과 $8 \%$, 야자계는 9,000 과 $12 \%$ 및 석탄계 $\mathrm{BV} 15,400$ 과 $19 \%$ 로 나타났다. 본 연구에서는 $\mathrm{HS}$ 의 파과시점을 정상상 태에 도달한 시점으로 선정하여 Freundlich 등온흡착식을 이 용하여 활성탄의 흡착용량을 평가하였다(Fig. 8).

$\mathrm{BB}$ 와 LMW-O의 경우도 생물분해에 의한 영향으로 파과는 유발되지 않았으며, 정상상태에 도달한 이후에 일정한 제거율 을 나타내었다. $\mathrm{BB}$ 의 경우 목탄계는 $\mathrm{BV} \mathrm{7,800} \mathrm{정도에} \mathrm{정상상}$ 태에 도달하여 $16 \%$ 정도의 제거율을 보였으며, 야자계와 석 탄계의 경우는 각각 $\mathrm{BV} 9,100$ 과 $21 \%$ 및 $\mathrm{BV} 16,000$ 과 $31 \%$ 정도의 제거율을 나타내었다. 그리고 $\mathrm{LMW}-\mathrm{O}$ 의 정상상태 도 달 시점과 정상상태 도달 이후의 제거율은 각각 BV 15,200(목 탄계) 21,000(석탄계) 및 21\% (목탄계) 42\% (석탄계) 정도로 나타났다. $\mathrm{HS}$ 에 비하여 정상상태 도달 후 $\mathrm{BB}$ 와 $\mathrm{LMW}-\mathrm{O}$ 의 제거능이 보다 높은 이유는 생물분해에 의한 영향으로 HS에 비해 $\mathrm{BB}$ 와 LMW-O의 생물분해 비율이 높기 때문이다. ${ }^{4)}$ 또한, $\mathrm{HS}$ 와 마찬가지로 $\mathrm{BB}$ 와 $\mathrm{LMW}-\mathrm{O}$ 의 경우도 파과에 도달하지 않아 정상상태에 도달하는 시점을 파과시점으로 선정하여 Freundlich 등온흡착식을 이용하여 활성탄의 흡착용량을 평가 하였다(Fig. 8).

Fig. 5에는 석탄계, 야자계 및 목탄계 활성탄 흡착컬럼 운전 초기(BV 70)에 유입수와 유출수를 LC-OCD-OND를 이용하 여 분석한 크로마토그램을 나타내었다. Fig. 5(a)에 나타낸 석 탄계 활성탄을 충진한 흡착컬럼 처리수의 크로마토그램을 보 면 머무름 시간(retention time, RT) 20 30분 사이에 검출되는 biopolymers (BP)는 전혀 흡착·제거되지 않고 유출되는 경향 을 나타내고 있으며, LMW-O를 구성하는 LMW-neutrals (LMW-neu)의 경우도 일부 유출되는 것을 볼 수 있다. BP와 LMW-neu는 석탄계 재질의 활성탄뿐만 아니라 야자계와 목탄
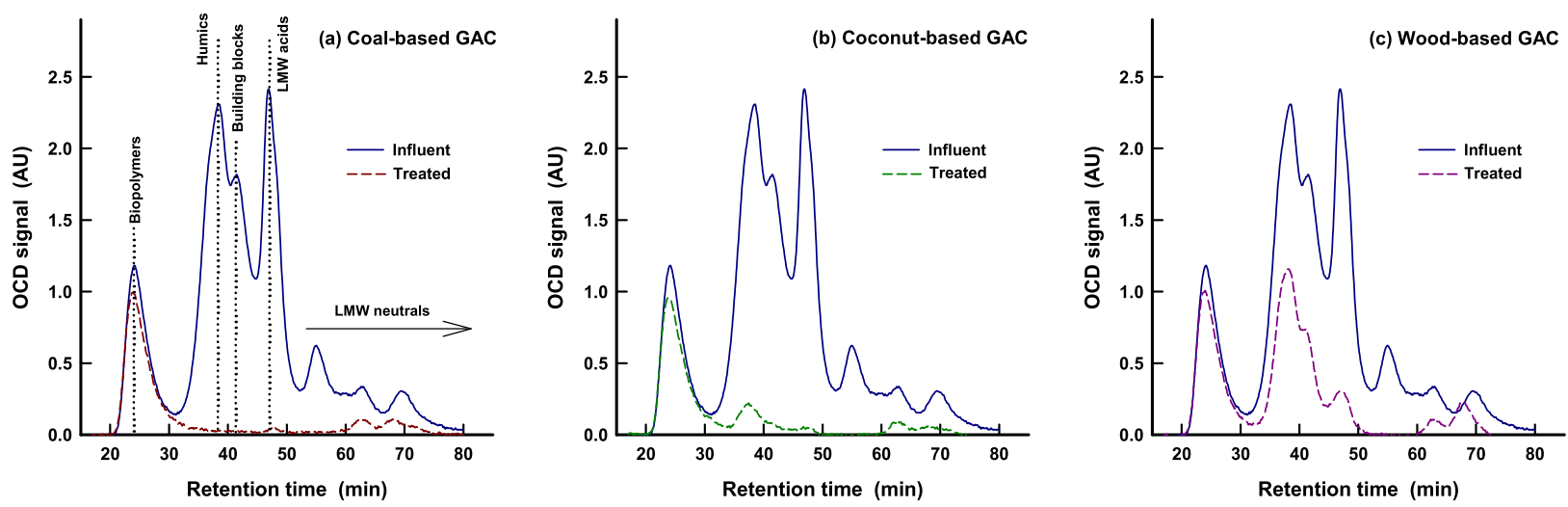

Fig. 5. LC-OCD chromatograms for influent and effluent concentrations of coal-, coconut- and wood-based GACs in the initial operation (BV 70). 

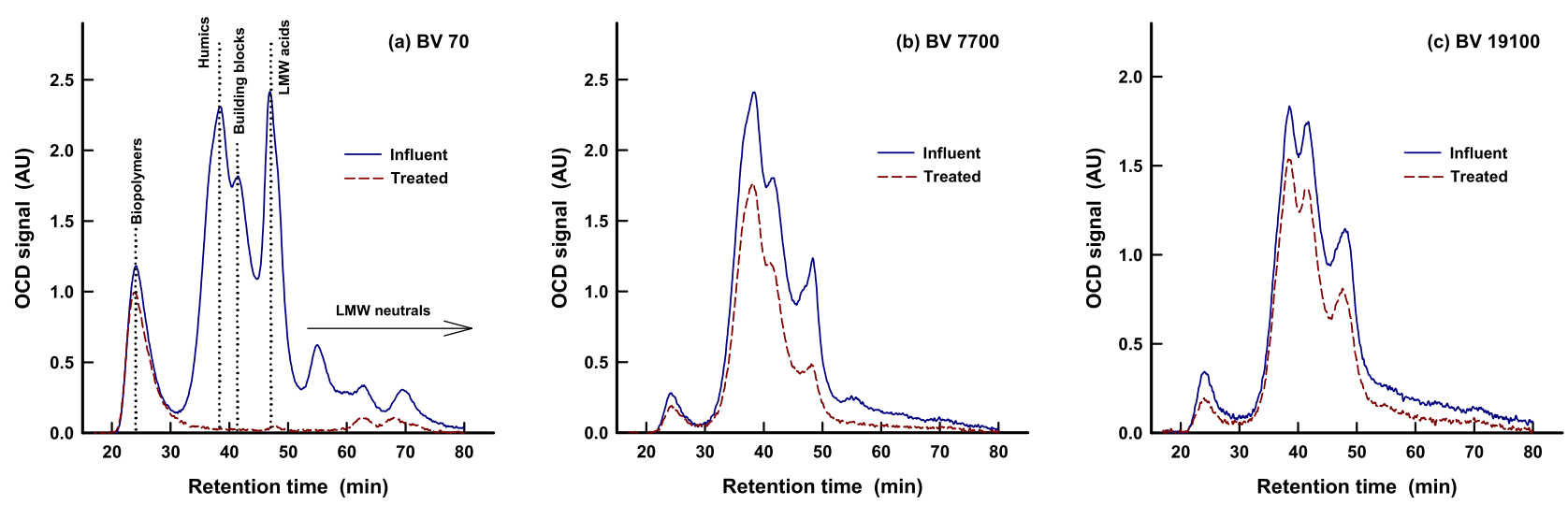

Fig. 6. LC-OCD chromatograms for influent and effluent concentrations with increasing operation time of coal-based GAC.
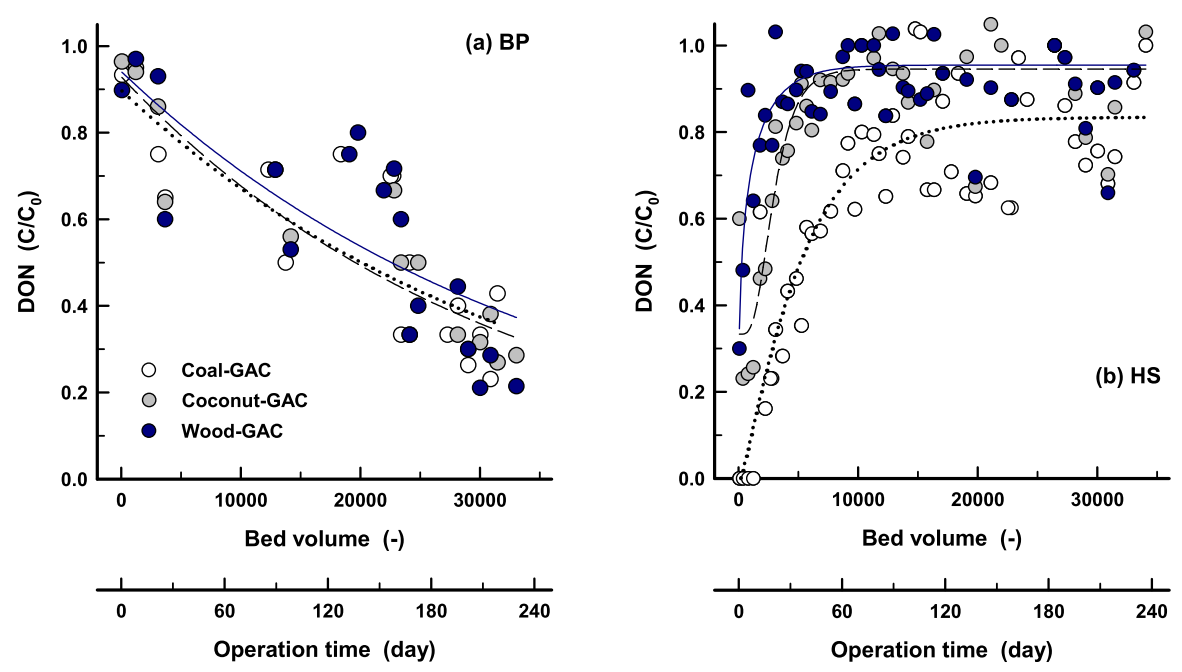

Fig. 7. Breakthrough curves of BP-DON and HS-DON by coal-, coconut- and wood-based GACs.

계 재질의 활성탄에서도 공통적으로 유사한 유출현상을 보이 고 있다. Table 3에서 볼 수 있듯이 LMW-neu의 경우는 분자량 350 이하의 친수성 저분자 물질들로 구성되어져 있어 생물분 해의 용이성으로 인해 배·급수관망으로 유출될 경우 미생물 재 성장을 유발할 가능성이 높은 물질군이다. 또한, 야자계 및 목탄 계 재질의 활성탄을 충진한 컬럼 처리수(Fig. 5(b)와 Fig. 5(c))의 경우는 머무름 시간(retention time, RT) 35 40분 사이 에 검출되는 humic substances (HS)가 완전히 흡착·제거되지 않고 유출되는 것을 볼 수 있다.

Fig. 6에는 석탄계 활성탄 흡착컬럼 운전초기(BV 70)부터 운전기간 증가에 따른 유입수와 처리수의 LC-OCD-OND 분 석 크로마토그램을 나타내었다. 운전초기에는 완전히 흡착제거되었던 HS의 peak이 운전기간이 증가할수록 점진적으로 커지는 것을 볼 수 있으며, 이와 동시에 RT 40분 이후에 나타 나는 BB와 LMW-O 물질군들 peak의 크기도 점진적인 증가현 상을 보였다. 그러나 $\mathrm{BP}$ 의 경우는 운전기간에 따른 유입수에 서의 농도 차이는 있으나 운전기간 증가에 따라 유입수 대비 peak의 감소현상이 명확히 나타나고 있다.
Fig. 7(a)와 (b)에는 $\mathrm{BP}$ 와 $\mathrm{HS}$ 에 함유되어 있는 용존 유기질 소(dissolved organic nitrogen, DON)에 대한 활성탄 재질별 운전기간 경과에 따른 잔존비 변화를 나타내었다. Fig. 7(a)에 나타낸 $\mathrm{BP}$ 의 $\mathrm{DON}$ 잔존비 변화를 살펴보면 $\mathrm{BP}$ 에 함유된 $\mathrm{DOC}$ 의 잔존비 변화(Fig. 4(a))와 매우 유사한 것을 볼 수 있으며, $\mathrm{BP}$ 에 함유되어 있는 유기질소( $\mathrm{DON})$ 의 경우도 유기 탄소(DOC)와 마찬가지로 활성탄 표면에 생물막이 형성되면 생물분해에 의해 쉽게 제거되는 것으로 평가되었다. 또한, Fig. 7(b)에 나타낸 $\mathrm{HS}$ 의 DON 잔존비 변화의 경우도 $\mathrm{DOC}$ 의 잔존비 변화(Fig. 4(b))와 매우 유사하게 운전초기에는 흡착 에 의해 용이하게 제거되었으나 운전기간이 증가함에 따라 점진적으로 파과에 도달하였으며, 파과 도달시점과 파과 도 달 이후의 제거율의 경우도 DOC 파과특성과 매우 유사하였 다. 이와 같이 $\mathrm{BP}$ 와 $\mathrm{HS}$ 에 함유되어 있는 $\mathrm{DOC}$ 와 $\mathrm{DON}$ 이 유사하게 거동하는 것은 유기탄소와 유기질소가 $\mathrm{BP}$ 와 $\mathrm{HS}$ 를 구성하는 거대분자에 함유되어 있으며, $\mathrm{BP}$ 의 경우는 거대분 자(BP)가 생물분해에 의해 저분자화되면서 유기탄소와 유기 질소가 함께 생물분해되기 때문이며, 난분해성 $\mathrm{HS}$ 의 경우는 

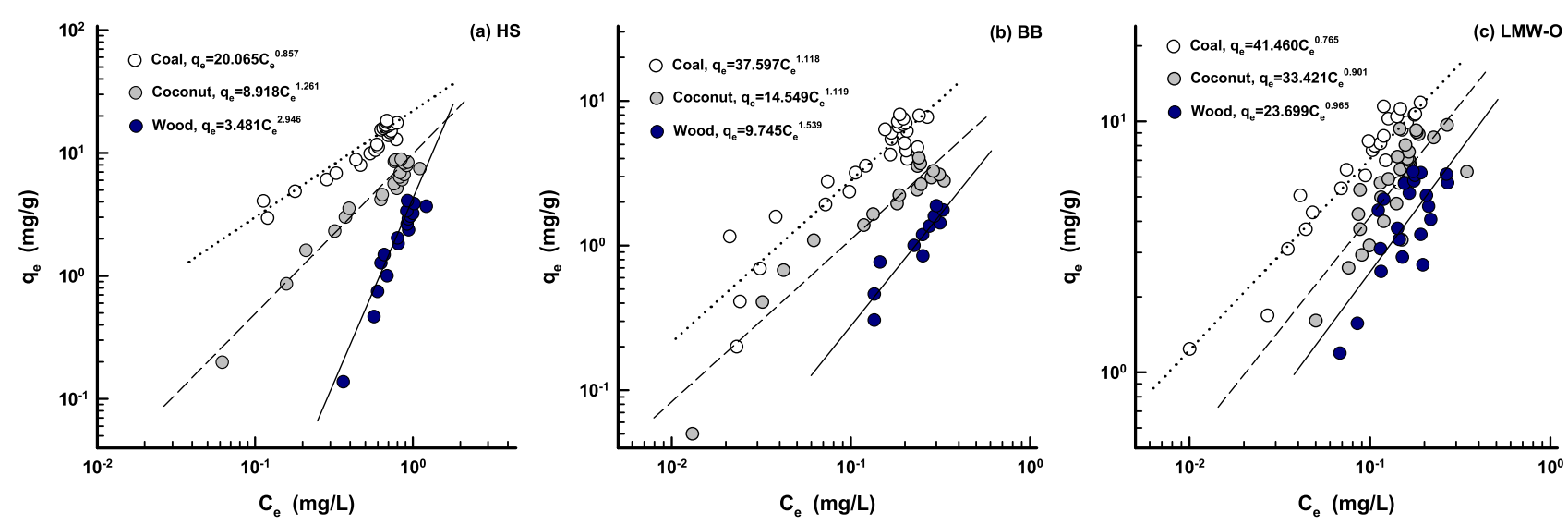

Fig. 8. Adsorption isotherms of individual NOM fractions calculated for coal-, coconut- and wood-based GACs at pseudo steady state.

Table 4. Bed life (BV $\mathrm{Bteady}_{\text {-state, }}$ Day steady-state) of for each NOM fractions.

\begin{tabular}{ccccccc} 
& \multicolumn{2}{c}{ Coal-based GAC } & \multicolumn{2}{c}{ Coconut-based GAC } & \multicolumn{2}{c}{ Wood-based GAC } \\
\cline { 2 - 7 } Fractions & $\begin{array}{c}\mathrm{BV}_{\text {steady-state }} \\
(-)\end{array}$ & $\begin{array}{c}\text { Daysteady-state } \\
(\text { day })\end{array}$ & $\begin{array}{c}\mathrm{BV}_{\text {steady-sate }} \\
(-)\end{array}$ & $\begin{array}{c}\text { Daysteady-state } \\
(\text { day })\end{array}$ & $\begin{array}{c}\mathrm{BV}_{\text {steady-state }} \\
(-)\end{array}$ & $\begin{array}{c}\text { Daysteady-state } \\
(\text { day) }\end{array}$ \\
\hline Total DOC & 16,200 & 113 & 9,500 & 66 & 7,600 & 53 \\
\hline HS DOC & 15,400 & 107 & 9,000 & 63 & 6,800 & 47 \\
\hline BB DOC & 16,000 & 111 & 9,100 & 63 & 7,800 & 54 \\
\hline LMW-O DOC & 21,000 & 146 & 15,200 & 106 & 15,200 & 106 \\
\hline HS DON & 17,000 & 118 & 9,100 & 63 & 7,700 & 53 \\
\hline
\end{tabular}

Table 5. Adsorption capacities $\left(q_{e}\right)$ and partition coefficients $\left(K_{p}\right)$ of DOC and individual NOM fractions calculated for coal-, coconut- and wood-based GACs at pseudo steady state.

\begin{tabular}{cccccccc} 
Fractions & \multicolumn{2}{c}{ Coal-based GAC } & \multicolumn{2}{c}{ Coconut-based GAC } & \multicolumn{2}{c}{ Wood-based GAC } \\
\cline { 2 - 7 } & $\begin{array}{c}q_{e} \\
(\mathrm{mg} / \mathrm{g})\end{array}$ & $\begin{array}{c}K_{p} \\
(\mathrm{~L} / \mathrm{g})\end{array}$ & $\begin{array}{c}q_{e} \\
(\mathrm{mg} / \mathrm{g})\end{array}$ & $\begin{array}{c}K_{p} \\
(\mathrm{~L} / \mathrm{g})\end{array}$ & $\begin{array}{c}q_{e} \\
(\mathrm{mg} / \mathrm{g})\end{array}$ & $\begin{array}{c}K_{p} \\
(\mathrm{~L} / \mathrm{g})\end{array}$ \\
\hline Total DOC & 41.1 & 32.8 & 24.4 & 18.6 & 13.9 & 7.8 \\
\hline HS DOC & 18.3 & 26.9 & 8.9 & 10.6 & 4.1 & 4.4 \\
\hline BB DOC & 8.1 & 42.6 & 4.0 & 16.7 & 1.9 & 6.3 \\
\hline LMW-O DOC & 11.9 & 59.5 & 9.7 & 35.9 & 6.3 & 35.3 \\
\hline
\end{tabular}

고분자 HS가 구조적 변형없이 흡착·제거되기 때문으로 평가 된다.

석탄계, 야자계 및 목탄계 활성탄 흡착컬럼에서 DOC 및 $\mathrm{NOM}$ 분획들에 대한 파과(정상상태) 도달 시점의 $\mathrm{BV}$ 와 운전 일수를 간략히 정리하여 Table 4에 나타내었다.

\section{2. 활성탄 재질별 흡착능 평가}

석탄계, 야자계 및 목탄계 재질 활성탄 흡착컬럼에서 운전기 간 증가에 따른 유입 및 유출수 중의 NOM 분획별 농도와 Freundlich 등온흡착식(식 (1))을 이용하여 흡착용량 $\left(q_{e}\right)$ 과 분 배계수 $\left(K_{p}\right)$ 를 계산하여 Fig. 8과 Table 5에 나타내었다. Table 5 에 나타낸 $\mathrm{DOC}$ 와 $\mathrm{NOM}$ 분획별 $q_{e}$ 와 $K_{p}$ 를 살펴보면 Total $\mathrm{DOC}$ 흡착용량 $\left(q_{e}\right)$ 의 경우는 석탄계가 야자계 및 목탄계 활성
탄에 비하여 대략 1.7 배 및 3.0 배 정도 높게 나타났으며, $\mathrm{HS}$, $\mathrm{BB}$ 및 LMW-O의 경우도 석탄계가 야자계와 목탄계에 비하여 각각 2.1 4.5배, 2.0 4.3배 및 1.2 1.9배 정도 높게 나타나 다른 재질의 활성탄보다 석탄계 재질의 활성탄의 NOM 분획별 흡 착능이 월등히 높은 것으로 나타났다. 이는 앞의 Table 2에 나타낸 활성탄 재질별 물리·화학적 특성과 관련이 있다. 활성 탄 단위 무게당 비표면적(specific surface area)과 세공용적 (pore volume)은 목탄계 재질의 활성탄이 석탄계나 야자계에 비하여 월등히 높게 나타났으나 실제 NOM 분획별 흡착능의 경우는 가장 낮은 흡착능을 나타내었다(Table 5). 이러한 이유 로는 Table 2에 나타낸 $\mathrm{pH}_{\mathrm{zpc}}$ 로 설명이 가능하며, 목탄계 재질 의 활성탄은 $\mathrm{pH} 4.1$ 이상에서는 표면전하가 음전하를 나타내 어 수중에 잔존하는 $\mathrm{NOM}$ 의 흡착에 매우 불리하며, 그에 비해 
석탄계나 야자계 재질의 활성탄들의 $\mathrm{pH}_{\mathrm{zpc}}$ 는 각각 7.0 과 6.5 정도로 활성탄 흡착컬럼 유입수의 $\mathrm{pH}$ 6.8 7.4와 매우 유사하 기 때문에 전하 반발에 의한 NOM 흡착능 감소는 목탄계 재질 의 활성탄에 비하여 매우 미미한 것으로 나타났다. Son 등의 연구결과 ${ }^{11}$ 에서는 목탄계 재질의 활성탄의 경우는 활성탄 제 조시 세공형성 단계(활성화(activation) 단계)에서 화학약품을 이용하기 때문에 열을 이용한 활성화(thermal activation)를 거치는 석탄계나 야자계 재질의 활성탄과 비교하여 활성탄 세공에서의 표면전하에 많은 차이가 발생한 것으로 평가하고 있다.

또한, $\mathrm{NOM}$ 분획별 흡착용량 $\left(q_{e}\right)$ 을 비교해보면 석탄계 활성 탄에서는 HS가 $18.3 \mathrm{mg} / \mathrm{g}$ 으로 가장 높게 나타났으며, 다음으 로 LMW-O가 $11.9 \mathrm{mg} / \mathrm{g}, \mathrm{BB}$ 가 $8.1 \mathrm{mg} / \mathrm{g}$ 순이었다. 그러나 야자계와 목탄계 활성탄의 경우는 LMW-O가 각각 $9.7 \mathrm{mg} / \mathrm{g}$ 및 $6.3 \mathrm{mg} / \mathrm{g}$ 으로 가장 높게 나타났으며, 다음으로 $\mathrm{HS}$ 가 각각 $8.9 \mathrm{mg} / \mathrm{g}$ 및 $4.1 \mathrm{mg} / \mathrm{g}, \mathrm{BB}$ 가 $4.0 \mathrm{mg} / \mathrm{g}$ 및 $1.9 \mathrm{mg} / \mathrm{g}$ 으로 순이었 다. 이와 같이 활성탄 재질별 차이를 나타내는 이유는 Fig. 1 에 나타낸 활성탄 재질별 세공용적 분포로 설명이 가능하다. 석탄 계 재질의 활성탄은 20 200 $\AA$ 부근의 중간세공(mesopore)이 발달해 있어 $\mathrm{HS}$ 와 같은 고분자 NOM의 흡착에 유리한 반면, 야자계 활성탄의 경우는 $20 \AA$ 이하의 미세세공이 발달해 있 어 LMW-O와 같은 저분자 물질의 흡착에 유리하다. 또한, 전 체적으로 흡착능이 저조한 목탄계 재질의 활성탄도 중간세공 에 비해 미세세공이 더욱 많이 분포하는 것을 Fig.1에서 볼 수 있다.

$\mathrm{DOC}$ 및 개별 $\mathrm{NOM}$ 분획의 흡착능을 비교하기 위해 정상 상태에 도달한 후 활성탄에 흡착된 양 $(\mathrm{mg} / \mathrm{g})$ 과 각각의 활성 탄 컬럼 처리수에 잔존하는 농도 $(\mathrm{mg} / \mathrm{L})$ 로부터 식 (2)를 사용 하여 분배계수 $\left(K_{p}\right)$ 를 계산하였다. 수중에 여러 물질들이 공 존할 경우, 이들 물질들이 활성탄에 흡착가능한 물질들일 경우 수중에 높은 농도로 잔존하는 물질의 흡착용량이 높게 평가된다. 따라서 이와 같은 영향을 배제하기 위하여 분배계 수 $\left(K_{p}\right)$ 를 이용하여 NOM 분획별 활성탄에 대한 흡착능을 평가하였다.

Table 5에서 볼 수 있듯이 분배계수 $\left(K_{p}\right)$ 는 다양한 재질의 활성탄들 모두에서 $\mathrm{NOM}$ 분획들의 분자량이 작을수록 분배 계수 $\left(K_{p}\right)$ 가 증가하였다. 분자량이 더 작은 $\mathrm{NOM}$ 분획들이 더 큰 흡착능을 나타내는 이유는 전체 세공들에 대한 더욱 높은 접근성, 즉 분자량이 큰 NOM 물질들 보다 작은 NOM 물질이 큰 세공부터 작은 세공(micropore)까지 모두 접근이 가능하기 때문이다. 활성탄에 대한 높은 흡착용량 $\left(q_{e}\right)$ 을 보 인 $\mathrm{HS}$ 의 경우는 정상상태 도달 이후에 활성탄에 흡착된 양 (흡착용량)은 많지만 수중에 잔존하는 농도도 다른 NOM 분획들에 비하여 훨씬 높기 때문에 분배계수 $\left(K_{p}\right)$ 가 작게 나 타났다.

\section{4. 결 론}

$\mathrm{GAC}$ 흡착공정에서 높은 NOM 제거 효율을 달성하려면 활 성탄이 가지는 세공의 비표면적, 세공용적 및 세공의 폭이 커야 할 뿐만 아니라 $\mathrm{pH}_{\mathrm{zpc}}$ 도 중성 $\mathrm{pH}$ 부근 이상으로 높아야 $\mathrm{NOM}$ 흡착능이 높게 나타났다. 또한, NOM 분획들에서는 biopolymers (BP)가 GAC에 흡착되지 않은 반면, 나머지 NOM 분획의 흡착능은 $\mathrm{NOM}$ 분획들의 분자량이 감소함에 따라 증 가하였다. LMW-organics (LMW-O)의 흡착능이 가장 높았고, 다음으로 building blocks (BB), humic substances (HS), BP 순으로 나타났다. BP와 $\mathrm{HS}$ 는 국내·외의 정수장에 많이 도입 되어 있는 membrane의 오염에 있어서 중요한 역할을 한다. 본 연구에서는 $\mathrm{GAC}$ 공정의 흡착 메카니즘으로는 $\mathrm{BP}$ 가 제거 되지 않았음을 보여주었다. 또한, $\mathrm{HS}$ 는 운전 초기에는 흡착 제거되었으나 운전 기간이 증가할수록 다른 NOM 분획들에 비해 급격히 흡착 용량이 감소하였다. 따라서 $\mathrm{GAC}$ 흡착공정 은 membrane의 오염물질 제거를 위한 효과적인 전처리 기술 이 될 것으로 기대되지는 않는다. DBPs 전구물질의 관점에서 보면 이전 연구결과에서 고분자 휴믹물질과 저분자 비휴믹 분획들에서의 DBPs 생성수율 $(\mu \mathrm{mol} \mathrm{DBP} / \mu \mathrm{mol} \mathrm{C})$ 이 유사하 다는 것을 보여주었다. ${ }^{39)}$ 따라서 $\mathrm{GAC}$ 흡착공정은 더 높은 비율의 저분자 NOM을 함유하는 물에서 DBP 전구물질 제어 에 더 효과적임을 시사한다.

\section{References}

1. J. Swietlik, A. Dabrowska, U. Raczyk-Stanislawiak, J. Nawrocki, Reactivity of natural organic matter fractions with chlorine dioxide and ozone, Water Res., 38(3), 547-558(2004).

2. Y. S. Kim, H. J. Son, C. D. Seo, H. Y. Kim, W. T. Lee, I. S. Hwang, Evaluation of NOM characteristics and disinfection by-products (DBPs) formation potential in Nakdong River basin, J. Korean Soc. Environ. Eng., 40(12), 495-504(2018).

3. H. J. Son, Y. D. Hwang, J. S. Roh, K. W. Ji, P. S. Sin, C. W. Jung, L. S. Kang, Application of MIEX ${ }^{\circledR}$ pre-treatment for ultrafiltration membrane process for NOM removal and fouling reduction, Water Sci. Technol.: Water Supply, 5(5), 15-24(2005).

4. H. J. Son, Y. S. Kim, S. G. Kim, Y. D. Hwang, I. S. Hwang, Insight into biodegradation of dissolved organic matter fractions using LC-OCD-OND in drinking water treatment processes, J. Korean Soc. Environ. Eng., 41(1), 55-60(2019).

5. E. N. Hidayah, Y.-C. Chou, H.-H. Yeh, Comparison between HPSEC-OCD and F-EEM for assessing DBPs formation in water, J. Environ. Sci. Health, Part A: Toxic/Hazard. Subst. Environ. Eng. 52(4), 391-402(2017).

6. S. Sandron, A. Rojas, R. Wilson, N. W. Davies, P. R. Haddad, R. A. Shellie, P. N. Nesterenko, B. P. Kelleher, B. 
Paull, Chromatographic methods for the isolation, separation and characterisation of dissolved organic matter, Environ. Sci.: Processes Impacts, 17(9), 1531-1567(2015).

7. M. Heibati, C. A. Stedmon, K. Stenroth, S. Rauch, J. Toljander, M. Säve-Söderbergh, K. R. Murphy, Assessment of drinking water quality at the tap using fluorescence spectroscopy, Water Res., 125, 1-10(2017).

8. S. A. Huber, A. Balz, M. Abert, W. Pronk, Characterisation of aquatic humic and non-humic matter with size-exclusion chromatography-organic carbon detection-organic nitrogen detection (LC-OCD-OND), Water Res., 45(2), 879-885(2011).

9. R. K. Henderson, A. Baker, K. R. Murphy, A. Hambly, R. M. Stuetz, S. J. Khan, Fluorescence as a potential monitoring tool for recycled water systems: a review, Water Res., 43(4), 863-881(2009).

10. J. K. Wassink, R. C. Andrew, R. H. Peiris, R. L. Legge, Evaluation of fluorescence excitation-emission and LC-OCD as methods of detecting removal of NOM and DBP precursors by enhanced coagulation, Water Sci. Technol.: Water Supply, 11(5), 621-630(2011).

11. H. J. Son, J. S. Roh, S. G. Kim, S. M. Bae, L. S. Kang, Removal characteristics of chlorination disinfection by-products by activated carbons, J. Korean Soc. Environ. Eng., 27(7), 762-770(2005).

12. C. D. Seo, H. J. Son, J. T. Choi, P. J. Yoo, S. H. Jang, Occurrence of UV filters in Nakdong River basin: mainstreams, tributaries and STP effluents, J. Korean Soc. Environ. Eng., 37(8), 472-479(2015).

13. H. S. Yoom, H. J. Son, K. A. Kim, H. Y. Kim, D. C. Ryu, Occurrence of benzotriazoles, benzothiazoles and benzenesulfonamides in the wastewater treatment plant effluents in Nakdong River basin, J. Korean Soc. Environ. Eng., 40(3), 147-154(2018).

14. H. S. Yoom, H. J. Son, H. Y. Kim, D. C. Ryu, J. D. Shin, Y. H. Lee, C. W. Kim, Occurrence characteristics of parabens in Nakdong River basin, J. Korean Soc. Environ. Eng., 40(5), 193-202(2018).

15. H. J. Son, S. G. Kim, C. D. Seo, H. S. Yoom, D. C. Ryu, Evaluation of treatability on DOC and THMs according to periodic cumulative filling of granular activated carbon (GAC), J. Korean Soc. Environ. Eng., 39(9), 513-518(2017).

16. S. G. Kim, H. J. Son, Y. D. Hwang, H. S. Yoom, H. K. Park, Evaluation of water treatment efficiency according to number of regeneration of GACs for efficient operation of GAC process, J. Korean Soc. Environ. Eng., 40(4), 179-184 (2018).

17. D. M. Owen, G. L. Amy, Z. K. Chowdhury, Characterization of Natural Organic Matter and Its Relationship to Treatability, American Water Works Association Research Foundation, Denver, CO, USA(1993).

18. Y. Matsui, D. R. U. Knappe, K, Iwaki, H. Ohira, Pesticide adsorption by granular activated carbon adsorbers. 2. Effects of pesticide and natural organic matter characteristics on pesticide breakthrough curves, Environ. Sci. Technol., 36(15), 3432-3438(2002).
19. R. S. Summers, P. V. Roberts, Activated carbon adsorption of humic substances: II. size exclusion and electrostatic interactions, J. Colloid Interface Sci., 122(2), 382-397(1988).

20. G. Newcombe, Charge vs. porosity - some influences on the adsorption of natural organic matter (NOM) by activated carbon, Water Sci. Technol., 40(9), 191-198(1999).

21. G. Newcombe, M. Drikas, Adsorption of NOM onto activated carbon: electrostatic and non-electrostatic effects, Carbon, 35(9), 1239-1250(1997).

22. T. Karanfil, J. E. Kilduff, Role of granular activated carbon surface chemistry on the adsorption of organic compounds. 1. priority pollutants, Environ. Sci. Technol., 33(18), 3217-3224(1999).

23. M. C. Lee, V. L. Snoeyink, J. C. Crittenden, Activated carbon adsorption of humic substances, J. AWWA, 73(8), 440-446(1981).

24. C. Pelekani, V. L. Snoeyink, Competitive adsorption in natural water: role of activated carbon pore size, Water Res., 33(5), 1209-1219(1999).

25. K. Ebie, F. Li, Y. Azuma, A. Yuasa, T. Hagishita, Pore distribution effect of activated carbon in adsorbing organic micropollutants from natural water, Water Res., 35(1), 167-179(2001).

26. Q. Li, V. L. Snoeyink, B. J. Mariñas, C. Campos, Pore blockage effect of NOM on atrazine adsorption kinetics of PAC the roles of PAC pore size distribution and NOM molecular weight, Water Res., 37(20), 4863-4872(2003).

27. W. Cheng, S. A. Dastgheib, T. Karanfil, Adsorption of dissolved natural organic matter by modified activated carbons, Water Res., 39(11), 2281-2290(2005).

28. E. Vuorio, R. Vahala, J. Rintala, R. Laukkanen, The evaluation of drinking water treatment performed with HPSEC, Environ. Int., 24(5-6), 617-623(1998).

29. A. Matilainen, M. Vieno, T. Tuhkanen, Efficiency of the activated carbon filtration in the natural organic matter removal, Environ. Int., 32(3), 324-331(2006).

30. E. M. Perdue, C. R. Lytle, A distribution model for binding of protons and metal-ions by humic substances, Environ. Sci. Technol., 17(11), 654-660(1983).

31. G. Newcombe, J. Morrison, C. Hepplewhite, Simultaneous adsorption of MIB and NOM onto activated carbon. I. characterisation of the system and NOM adsorption, Carbon, 40(12), 2135-2146(2002).

32. H. J. Son, D. C. Ryu, S. H. Jang, Effect of pore structure change on the adsorption of NOM and THMs in water due to the increase of reactivation number of coal-based activated carbon, J. Korean Soc. Environ. Eng., 32(10), 965-972(2010).

33. S. G. Kim, H. J. Son, J. M. Jung, D. C. Ryu, P. J. Yoo, Evaluation of drinking water treatment efficiency according to regeneration temperatures of granular activated carbon (GAC), J. Environ. Sci. Int., 24(9), 1163-1170(2015).

34. S. Velten, D. R. U. Knappe, J. Traber, H.-P. Kaiser, U. von Gunten, M. Boller, S. Meylan, Characterization of natural organic matter adsorption in granular activated carbon 
adsorbers, Water Res., 45(13), 3951-3959(2011).

35. A. Antony, M. Bassendeh, D. Richardson, S. Aquilina, A. Hodgkinson, I. Law, G. Leslie, Diagnosis of dissolved organic matter removal by GAC treatment in biologically treated papermill effluents using advanced organic characterisation techniques, Chemosphere, 86(8), 829-836(2012).

36. S. A. Huber, F. H. Frimmel, Size-exclusion chromatography with organic carbon detection (LC-OCD): a fast and reliable method for the characterization of hydrophilic organic matter in natural waters, Vom Wasser, 86, 227-290(1996).

37. K. J. Wilkinson, E. Balnois, G. G. Leppard, J. Buffle, Characteristic features of the major components of freshwater colloidal organic matter revealed by transmission electron and atomic force microscopy, Colloids Surf., A, 155(2-3), 287-310(1999).

38. H. J. Son, S. J. Yoo, J. S. Roh, P. J. Yoo, Biological activated carbon (BAC) process in water treatment, J. Korean Soc. Environ. Eng., 31(4), 308-323(2009).

39. A. Imai, K. Matsushige, T. Nagai, Trihalomethane formation potential of dissolved organic matter in a shallow eutrophic lake, Water Res., 37(17), 4284-4294(2003).

\section{Authors}

\section{Heejong Son}

Water Quality Institute, Busan Water Authority, Researcher, ORCID(i) 0000-0002-7950-8223

\section{Hoon-Sik Yoom}

Water Quality Institute, Busan Water Authority, Researcher, ORCID(D) 0000-0002-4736-7235

\section{Chang-Dong Seo}

Water Quality Institute, Busan Water Authority, Researcher, ORCID (1) 0000-0002-9650-8209

\section{Sang-Goo Kim}

Water Quality Institute, Busan Water Authority, Researcher, ORCID(D) 0000-0003-4977-8684

\section{Yong-Soon Kim}

Water Quality Institute, Busan Water Authority, Researcher, ORCID (1) 0000-0002-5395-6933 